Z. klin. Chem. u. klin. Biochem

9. Jg., S. 197-200, Mai 1971

\title{
A Note on Serum Nucleotidase Determinations
}

\author{
By A. Belfield and D. M. Goldberg \\ From the Department of Chemical Patbology (Head, Dr. D. M. Goldberg), \\ Royal Hospital, Sheffield, England
}

(Eingegangen am 23. November 1970)

\begin{abstract}
Current methods for estimating 5'-nucleotidase activity in human serum are critically discussed. The requirements for specificity in the assay procedure are re-emphasised, special consideration being given to the absolute concentrations as well as the molar ratios of true and alternative substrates. Substrate-inhibition, described in a previous Report is believed to be due to a non-linear relationship between AMP concentration and optical density above $0.1 \mathrm{~mm}$.
\end{abstract}

Die gegenwärtig gebrauchten Methoden zur Bestimmung der 5'-Nuclcotidaseaktivität von menschlichem Serum werden kritisch besprochen. Die Erfordernisse für die Spezifität des Bestimmungsverfahrens werden nachdrücklich hervorgehoben; besondere Überlegungen werden sowohl hinsichtlich der absoluten Konzentrationen als auch der molaren Verhältnisse von echten und alternativen Substraten angestellt. Es ist anzunehmen, daß die Substrathemmung, die in einem früheren Bericht beschrieben wurde, von einem nichtlinearen Verhältnis zwischen AMP-Konzentration und optischer Dichte oberhalb $0,1 \mathrm{mM}$ abhängt.

In the past three years, we have described four methods for the determination of 5 -nucleotidase (EC 3.1.3.5) in human serum. The first is based upon magnesium activation (1). In two further reports, the $5^{\prime}$-nucleotidase was coupled with adenosine deaminase (EC 3.5.4.4) and rate measurements were made at $265 \mathrm{~nm}(2)$ and at $340 \mathrm{~nm}$ (3). Finally, in a coupled reaction with adenosine deaminase the BERTHELOT reaction was used for the colorimetric measurement of the ammonia produced (4). The last three techniques take advantage of a high concentration of $\beta$-glycerophosphate to suppress hydrolysis of 5'-AMP by non-specific alkaline phosphatase $(5,6)$. Concurrently, and in a number of independent publications, a colorimetric method similar to that of reference (4) has been presented by PERSIJN, VAN DER SIIK, and their collaborators (7-10). The last of these papers (10) contains a number of statements which we consider to be in need of clarification. We shall attempt to summarise the requirements for specificity in the determination of 5'-nucleotidase activity.

\section{Requirements for specificity}

\section{Substrate Concentration}

Table 1 of reference (10) draws attention to the small substrate concentrations used in spectrophotometric assajs relative to those used in colorimetric assays. Our spectrophotometric assay (2) employs only $20 \mu l$ of serum in place of $100 \mu l$ (7) and the reaction is monitored over $20 \mathrm{~min}$. instead of $60 \mathrm{~min}$. (7), so

Tab. 1 Change in absorbance at $265 \mathrm{~nm}$ on incubating $20 \mathrm{U}$ adenosine deaEAAT) with 5'-AMP under conditions of BELFIELD and GOLDBERG (2) for two hours in presence and absence of $\beta$-glycerophosphate

\begin{tabular}{|c|c|c|}
\hline $\begin{array}{l}\text { adenosine } \\
\text { deaminase }\end{array}$ & $\begin{array}{c}\beta \text {-glyce } \\
\text { present }\end{array}$ & $\begin{array}{l}\text { sphate } \\
\text { absent }\end{array}$ \\
\hline $\begin{array}{l}\text { Lot } 7170103 \\
\text { Lot } 7220203\end{array}$ & $\begin{array}{r}+0.006 \\
0.000\end{array}$ & $\begin{array}{l}-0.019 \\
-0.016\end{array}$ \\
\hline
\end{tabular}

that in the course of the assay, the method in reference (7) consumes fifteen times more substrate than our spectrophotometric method.

However, this in no way justifies the excessively high substrate concentration $(5 \mathrm{mM})$ used by these authors since their own data (Fig. 3 of reference 10) show that $1 \mathrm{mM}$ AMP is more than sufficient to sustain optimal activity. Their complaint that optimal substrate concentration cannot be evaluated by the spectrophotometric assay is surprising, since we have already published a value for $K_{m}$ of 5 '-nucleotidase based upon this assay (4). We have repeated this determination in quadruplicate at five concentrations of AMP, and by application of a computerised statistical analysis of the data (11) derived a value of $9.82 \mu$ moles/litre (Standard Error $1.15 \mu$ moles) which is in good agreement with the figure of $11 \mu$ moles/litre obtained by LEYBOLD and colleagues $(12,13)$. This means that our substrate concentration ( $0.1 \mathrm{~mm}$ ) theoretically supports $91 \%$ of $\mathrm{V}_{\max }$ and in practise this figure is closer to $97 \%$ (12). Reference (10) cites a personal communication by one of us (D. M. G.) to the effect that substrate inhibition takes place above $0.12 \mathrm{mM}$ AMP. This statement has never been made by us; on the contrary, we have published substrate-velocity curves (3) showing under somewhat different reaction conditions a plateau in 5'-nucleotidase activity between $0.167 \mathrm{~mm}$ and $0.5 \mathrm{~mm}$ provided that full suppression of non-specific alkaline phosphatase is achieved (Fig. 1). LEYBOLD and colleagues $(12,13)$ claimed that such substrate inhibition did in fact occur, but they were working at optical densities greater than 2.7. AMP and inosine solutions obey the BEER-LAMBERT Law at $265 \mathrm{~nm}$ and $\mathrm{pH} 7.9$ to O. D. 1.9; beyond this, the relationship is nonlinear, and complex calibration curves using both AMP and inosine are needed to convert $O$. D. changes to the actual amount of substrate consumed. It is probable that this necessity was not realised by LEYBOLD 


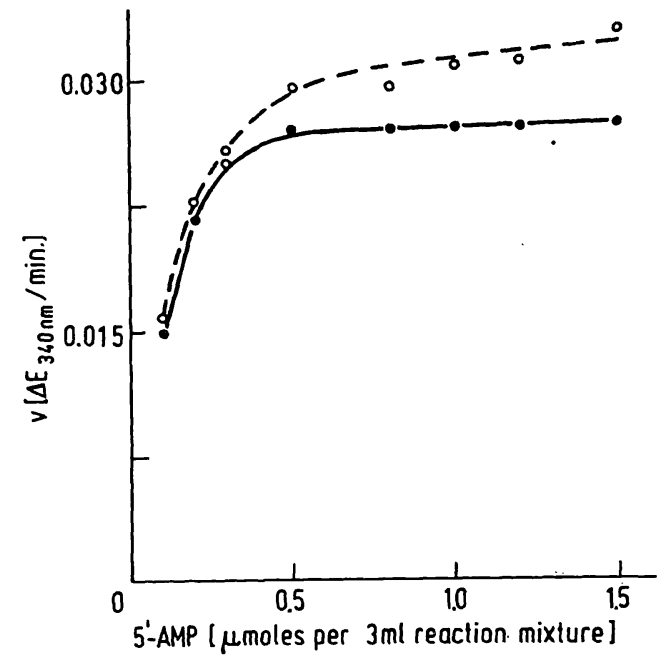

Fig. 1

Hydrolysis by human serum of 5'-AMP measured by coupled kinetic assay at $340 \mathrm{~nm}$ (3) with increasing concentrations of $5^{\prime}$-AMP. The ratio of $\beta$-glycerophosphate to 5 -AMP is maintained at $15: 1(0)$ and at $150: 1(\bullet)$. Alkaline phosphatase activity of serum was 102 King Units per $100 \mathrm{ml}(19)$.

and colleagues, leading to a progressive underestimate of enzyme activity as substrate, and therefore, $\mathbf{E}_{\mathbf{2 6 5}}$ was increased.

\section{Alternative Substrate Concentration}

In our original description of the phenomenon of enzyme diversion (5), and subsequently $(6,14)$, we have emphasised the importance of a high molar ratio of the substrate for non-specific phosphatase relative to that of the specific phosphatase being measured. This ratio has never been less than 100:1 for any of the 5'-nucleotidase methods proposed by us. Yet the ratio of phenyl phosphate to AMP is only 8:5 in references $(9,10)$. This ratio is much too low for adequate suppression of alkaline phosphatase activity (Fig. 2). It is clear from Figs. 1 and 2 of reference (9) that increasing suppression of serum alkaline phosphatase takes place when the phenyl phosphate concentration is increased from $8 \mathrm{~mm}$ (the concentration used by these authors in their standard procedure ) to $25 \mathrm{~mm}$. A further contribution towards improving specificity would be achieved by lowering the AMP concentration to $1 \mathrm{mM}$; this would also reduce the value of the blank due to the presence of free adenosine in the substrate, which can contribute as much as $50 \%$ of the total O. D. of normal sera (15).

\section{Purity of adenosine deaminase}

Reference (10) indulges in prolonged speculative calculations and theorises on the effect that the contamination of commercial adenosine deaminase by AMP deaminase might have on the various methods. Our experiments on this point are presented in Table 1 which shows that when adenosine deaminase is used in 16-fold excess over the amount we normally employ, an apparent increase in $5^{\prime}$-nucleotidase activity equivalent to $3 \mathrm{IU} / l$ would be obtained if $\beta$-glycerophosphate were omitted. This shows that the contaminating

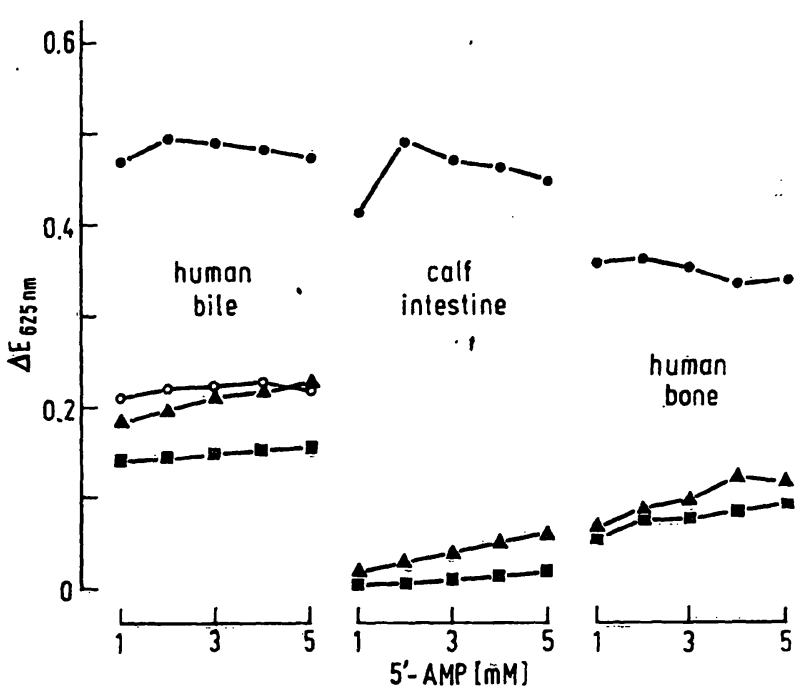

Fig. 2

Hydrolysis of 5'-AMP in absence and presence of various concentrations of disodium phenyl phosphate by fresh dialysed human bile diluted in glycerol (alkaline phosphatase activity 331 King Units per $100 \mathrm{ml}$ ), calf intestinal alkaline phosphatase from Boehringer Corporation (London) Ltd., Cat. No. 15436 EPAC, dialysed free of ammonia (activity 48 King Units per $100 \mathrm{ml}$ ), and a butanol preparation of human bone essentially according to MORTON (20) activity 150 King Units per $100 \mathrm{ml})$. (-) no phenylphosphate; (A-A) $8 \mathrm{mM},(--)$ $25 \mathrm{mM}$ phenylphosphate ; $(\circ-0)$ constant ratio 5'-AMP: phenylphosphate of $5: 8 \mathrm{~mm}$. $100 \mu \mathrm{l}$ of each preparation used under reaction conditions of PERSIJN (7-10) with colour development of same author and enzyme incubation time $30 \mathrm{~min}$. Alkaline phosphatase activity determined by method of KIND and KING (19). $\Delta E=E_{\text {test }}-E_{\text {blank }}$

enzyme in commerical adenosine deaminase preparations, previously thought to be AMP deaminase (7), is more probably a non-specific phosphatase, and is inhibited by the $\beta$-glycerophosphate which has been an integral part of all our 5'-nucleotidase assays utilising adenosine deaminase. In any case, the $\mathrm{pH}$ optimum of AMP deaminase, is 5.9 (16), which is far removed from $\mathrm{pH} 7.9$ at which our assay is conducted; and we have always recommended a system of reagent checks with each batch of determinations $(3,4)$.

\section{pH of Assay}

Persijn and colleagues employ a buffer at $\mathrm{pH} 7.5$ in their assay. They have not published a $\mathrm{pH}=$ activity curve using their method. We have shown, with two methods, that the $\mathrm{pH}$ optimum for serum $5^{\prime}$-nucleotidase is $7.9(1,4)$ and our assays are conducted at this $\mathrm{pH}$.

\section{Precision}

The authors of reference (10) complain that we have not stated the precision of our spectrophotometric method in the normal range. Previously (2) we gave an estimate of precision based upon replicate analyses of a serum with moderately raised activity. The precision of this method in the normal range was evaluated by calculating the standard deviation of pooled duplicates according to PEARson (17) using the data routinely accumulated in our laboratory, the value being $1.9 \mathrm{IU} / l$. This approximates to more than twice the variance claimed by the authors of reference (7) who have not, however, given this information for their most recent modification (9). 


\section{Sensitivity}

Reference (10) Table 3 gives a misleading impression of the relative sensitivities of our spectrophotometric method (2) and that of the former authors. When the data are expressed as theoretical $O$. D. change per hour per $\mathrm{ml}$ of serum, the spectrophotometric methods $(2,14)$ are $50 \%$ more sensitive than the colorimetric method of Persijn (7). Our own colorimetric method is, using the same criteria, the most sensitive yet described (4), but requires correction for inhibition of the BERTHELOT reaction caused by the synergistic action of serum and EDTA. PERsijn and colleagues have not satisfactorily met our criticism that they have failed to recognise this inhibition. Until now, they have presented data for the recovery of adenosine (7) which averaged $98.1 \%$ (standard deviation $5.1 \%$ ), and made inferences based upon linearity between serum volume and O. D. (10, Fig. 1) and EDTA concentration (10, Fig. 2). In none of this work is it clearly stated whether ammonia standards were employed. Using their method exactly as published (7-9), we found a consistent difference averaging $5 \%$ between the O. D. generated by aqueous ammonia in the presence and absence of $100 \mu l$ serum (Fig. 3) after making allowance for the ammonia content of the serum. This is additional to the inhibition due to veronal and EDTA, amounting to approximately $5 \%$, but allowed for by the device of preparing adenosine standards in veronal and including EDTA during colour development. With a fixed concentration of ammonia, increasing the volume of serum in the reaction mixture causes a linear decrease in O. D. (Fig. 4); this line was derived statistically from a least-squares fit, and the inhibition with $100 \mu l$ serum was $4.5 \%$. This is much less than the inhibition of about $15 \%$ occurring in our method (4). Since we use the concentrated reagents of CHANEY and Marbach (16) whereas Persijn and colleagues use these reagents in the dilutc form, the concentration of EDTA and serum and therefore the extent of inhibition is greater in our system, but at the same time sensitivity is also increased.

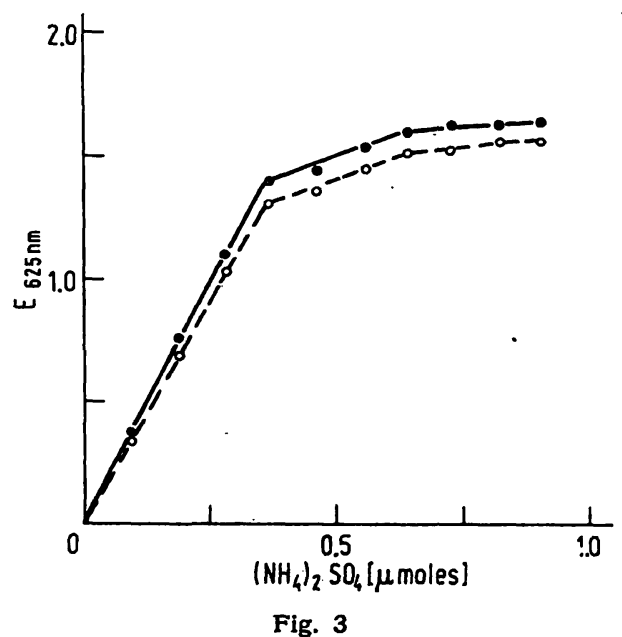

Absorbance at $625 \mathrm{~nm}$ of $\left(\mathrm{NH}_{4}\right)_{2} \mathrm{SO}_{4}$ solutions measured by method $100 \mu l$ pooled human serum. Final volume of reaction mixture, which included buffer and $\mathbf{M g}^{++}$, maintained constant.

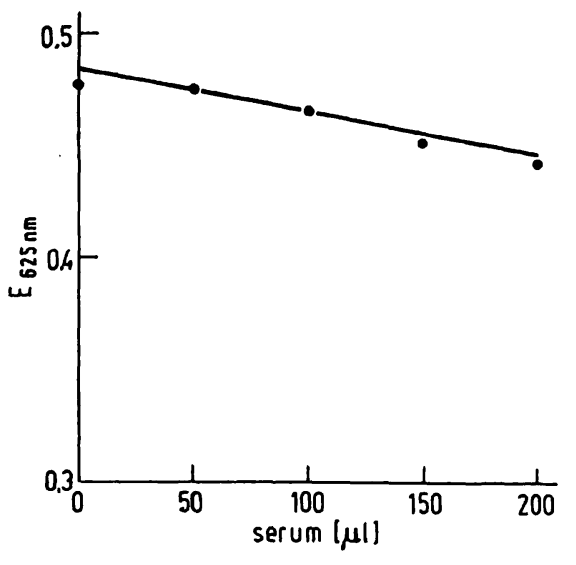

Fig. 4

Absorbance at $625 \mathrm{~nm}$ of $0.125 \mu$ moles $\left(\mathrm{NH}_{4}\right)_{2} \mathrm{SO}_{4}$ measured by method of PERSIJN (7) in presence of buffer and $\mathrm{Mg}^{++}$but varying volume of pooled human serum, with total volume of reaction mixture maintained constant

\section{Tissue Specificity}

In Fig. 2 human hepatic 5'-nucleotidase, present in the bile, shows, under the conditions of PersijN (7-10), little increase in activity with increase in $5^{\prime}$-AMP concentration. Hydrolysis of 5'-AMP is constant when the molar ratio of 5'-AMP to phenyl phosphate is held constant at 5:8. When phenyl phosphate is held constant at $8 \mathrm{~mm}$, increased hydrolysis of $5^{\prime}$-AMP occurs with increasing concentration of the latter since the alteration in the ratio favours its hydrolysis by nonspecific alkaline phosphatase. The two lines meet when the absolute concentrations of phenyl phosphate and $5^{\prime}$-AMP are $8 \mathrm{~mm}$ and $5 \mathrm{~mm}$ respectively. The hydrolysis of $5^{\prime}$-AMP in the presence of $25 \mathrm{~mm}$ phenyl phosphate is less than in the previous two cases, is less susceptible to changes in $5^{\prime}$-AMP concentration favouring hydrolysis of the latter by alkaline phosphatase, and thus provides a more accurate measure of true 5 '-nucleotidase activity. The results for the intestinal and bone preparations lead to a similar interpretation. It will however be apparent that these preparations differ in the ratio of true 5'-nucleotidase to alkaline phosphatase present in the material; in the affinity of its alkaline phosphatase for 5'-AMP (intestinal phosphatase having the highest affinity); and in the susceptibility of its alkaline phosphatase to phenyl phosphate - induced suppression of 5'-AMP hydrolysis (bone phosphatase being least susceptible). This last point accords with the previously-documented resistance of human bone phosphatase to $\beta$-glycerophosphate-induced suppression of 5'-AMP hydrolysis (5).

\section{Conclusions}

In our view, the spectrophotometric assay at $265 \mathrm{~nm}$ (2) is the most specific method currently available. The spectrophotometric assay at $340 \mathrm{~nm}$ (3) is less sensitive, and the reagents are more expensive, but it is potentially capable of adaptation to automatic analysis. The method described by us (4) is the most sensitive colorimetric procedure and is very suitable for paediatric 
work, but a substantial correction for colour inhibition is needed. The method of Persijn and colleagues (7-10) requires a much smaller correction for colour inhibition, and in practise this could virtually be ignored, but it employs five times as much serum and is not well suited to paediatric work. It could be very useful in adult work if the authors would modify their concentrations of true and alternative substrates in accordance with the advice we have offered.

\section{References}

1. Belfield, A. and D. M. Goldberg, J. clin. Path. 22, 144 (1969). - 2. Belfield, A. and D. M. Goldberg, Clin. Chem. N. Y. 15, 931 (1969). - 3. Ellis, G., A. Belfield and D. M. Goldrerg, 7th Int. Congr. Clin. Chem., Geneva, Sept. 1969 (Enzymol. biol. clin. 10, 349 (1969) abstr.). - 4. Belfreld, A., G. Elits and D. M. Goldaerg, Clin. Chem. N. Y. 16, 396 (1970). 5. Belfield, A. and D. M. Goldberg, Nature (London) 219, 73 (1968). - 6. Belfield, A. and D. M. Goldberg, Clin. Biochemistry 3, 105 (1970). - 7. Persijn, J.-P., W. VAN DER SLIK, K. KRAMER and C. A. DE Ruijter, This Journal 6, 441 (1968). 8. Persijn, J.-P., W. van der Slik, C. J. Timmer and A. W. M. Box, This Journal 7, 199 (1969). - 9. Persijn, J.-P., W. VAN DER Sirk and A. W. M. Bon, This Journal 7, 493 (1969). - 10. Persijn, J. P., W. van der Slik, C. J. Timmer and C. M. Reijnt-
JES, This Journal 8, 398 (1970). - 11. Hoy, T. G. and D. M. Goldberg, Int. J. Biomed. Computing (In Press). - 12. BeCKMANN, J., K. LEYBoLtD and L. WeIsBeCkER, This Journal 7, 18 (1969). - 13. LEYBOLD, K., J. BECKMAN and L. WEISBECKER, This Journal 7, 25 (1969). - 14. Belfield, A. and D. M. GoldbERG, Life Sciences 8, 129 (1969). - 15. Rosalki, S. B., Personal Communication. - 16. Nikiforuk, G. and S. P. Colowrck, in: Colowick-Kaplan (Eds.): Methods in Enzymology II, p. 469. Academic Press Inc., Publishers, New York (1955). - 17. Pearson, E. S., Biometrika 32, 307 (1941). - 18. Chaney, A. L. and E. P. Marbach, Clin. Chem. N. Y. 8, 130 (1962). - 19.KInd, P. R. N. and E. J. KING, J. clin. Path. 7, 322 (1954). - 20. Morton, R. K., Biochem. J. 57, 595 (1954).
Dr. D. M. Goldberg

Department of Chemical Pathology Royal Hospital

Sheffield

S1 3SR

England 


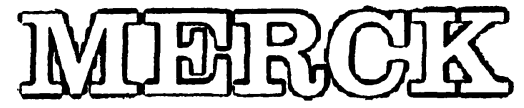

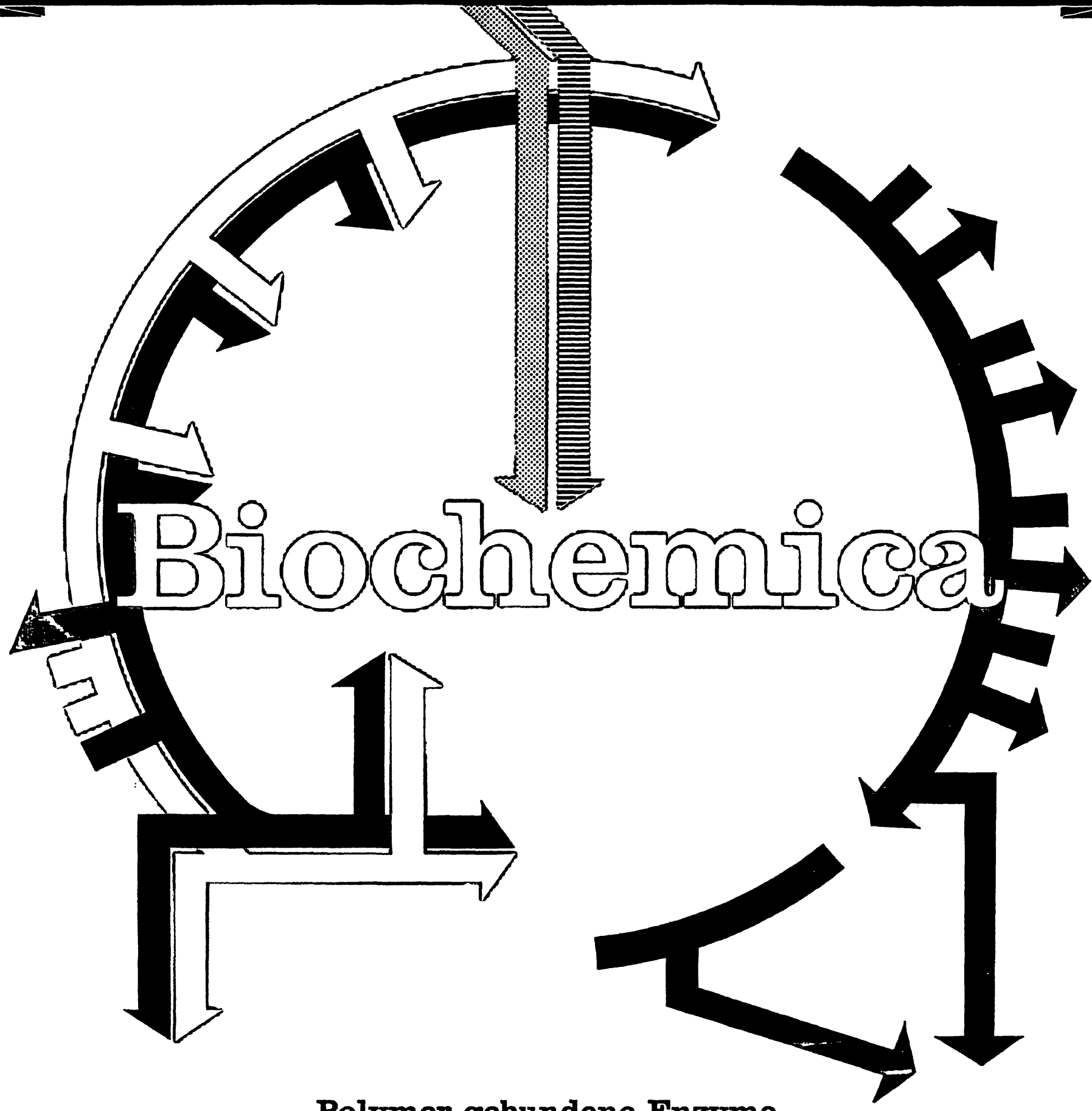

\section{Polymer gebundene Enzyme}

Bromelin - Chymotrypsin - Ficin - Papain - Pronase - Proteinase K (Tritirachium album) - Ribonuclease - Subtilisin - Trypsin (Rind) • Trypsin (Schwein) • Trypsin-Inhibitor (Sojabohnen)

\author{
Träger \\ Carboxymethylcellulose - Vernetztes Maleinsäureanhydrid \\ Besondere Vorteile \\ Hohe spezifische Aktivitäten - Enzymaktivität ausschließlich \\ kovalent gebunden - Gleichbleibende Qualität durch \\ Mindestaktivitätsangaben garantiert
}

Ausführliche Spezifikationen stehen auf Wunsch zur Verfügung. 


\section{Zum fehlerfreien} Photographieren von DünnschichtChromatogrammen CAMAG REPRO-STAR

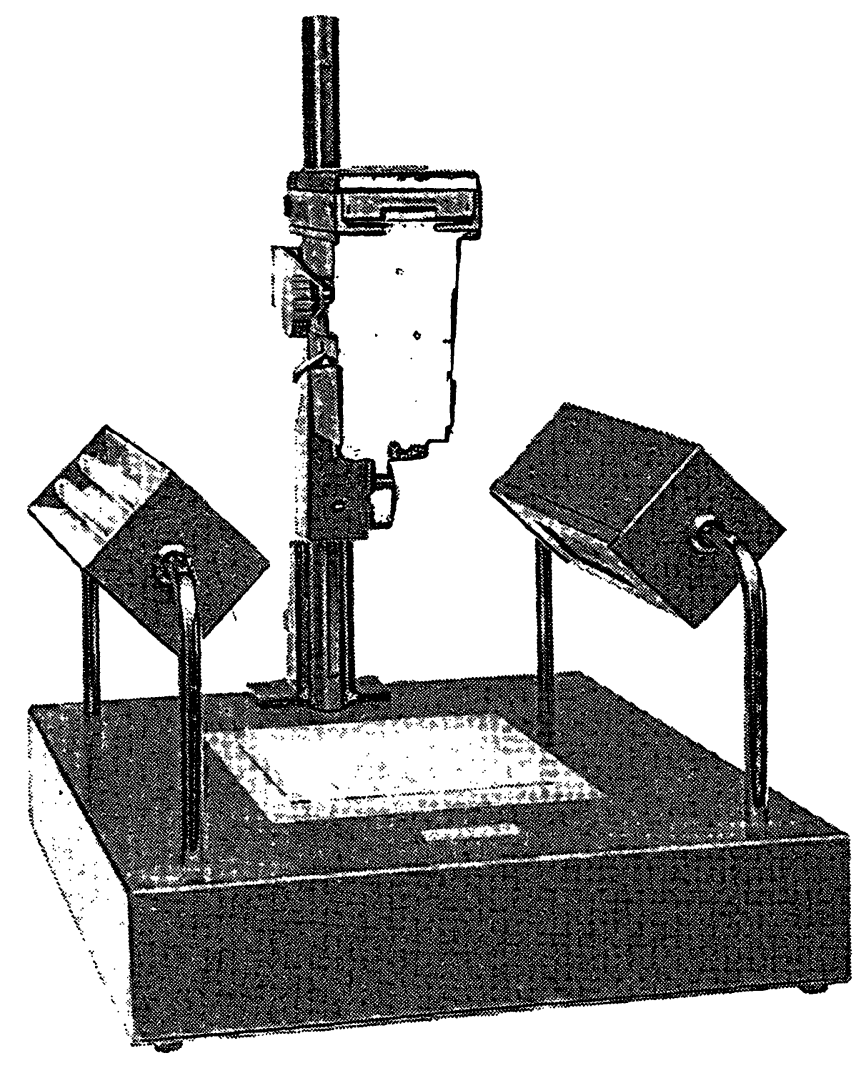

Mit dem CAMAG REPRO-STAR

photographieren Sie unter langwelligem UV, kurzwelligem UV und im sichtbaren Licht, im Auflicht- oder im Durchlichtverfahren.

Der REPRO-STAR ist so konstruiert, dass jede Aufnahme einwandfrei gelingt: Richtige Belichtungszeit, richtige Blende, richtige Scharfeinstellung und zwar mit jeder Kamera. (Ein Kamerawechsel dauert nur Sekunden.) Verlangen Sie unser ausführliches Angebot.

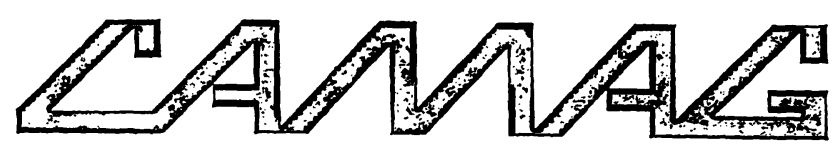

Homburgerstrasse 24 4132 Muttenz/Schweiz

Unser Zweigbetrieb in der Bundesrepublik:

1 Berlin 45, Baseler Strasse 65

Führend in Dünnschicht-Chromatographie Dünnschicht-Elektrophorese TL 39 Hochspannungs-Elektrophorese
BILTZ - KLEMM - FISCHER Experimentelle Einführung
in die anorganische Chemie

Neu herausgegeben von W. KLEMM und W. FISCHER 63.-70. Auflage

Oktav. XII, 228 Seiten. 1970. Balacron flexibel DM 21,-

Die Kürzung der Dauer des Chemiestudiums führt besonders zu einer Kürzung der,experimentellen Ausbildung, andererseits müssen im Ânfang grundlegende Stoffkenntnisse anhand der wichtigsten Ordnungsprinzipien vermittelt werden.

Um den heutigen Forderungen einer solchen Einführung Rechnung zu tragen, wurde das Werk überarbeitet und teilweise geändert. Während vom experimentellen Teil nur einige auf die analytische Chemie bezogene Versuche gestrichen wurden, erfuhren die theoretischen Abschnitte bei der Anpassung auf den heutigen Stand stärkere Änderungen. Neu gestaltet wurden insgesamt die Kapitel: Anwendungen des Massenwirkungsgesetzes, Oxidations-Reduktions-Potentiale. Bei der Behandlung von Säure-Basen-Gleichgewichten wurde der historischen Entwicklung von Davy und Liebig über Arrhenius und Ostwald zu Brönsted Rechnung getragen; im weiteren Verlauf werden aber nur noch die Brönstedschen Definitionen verwandt.

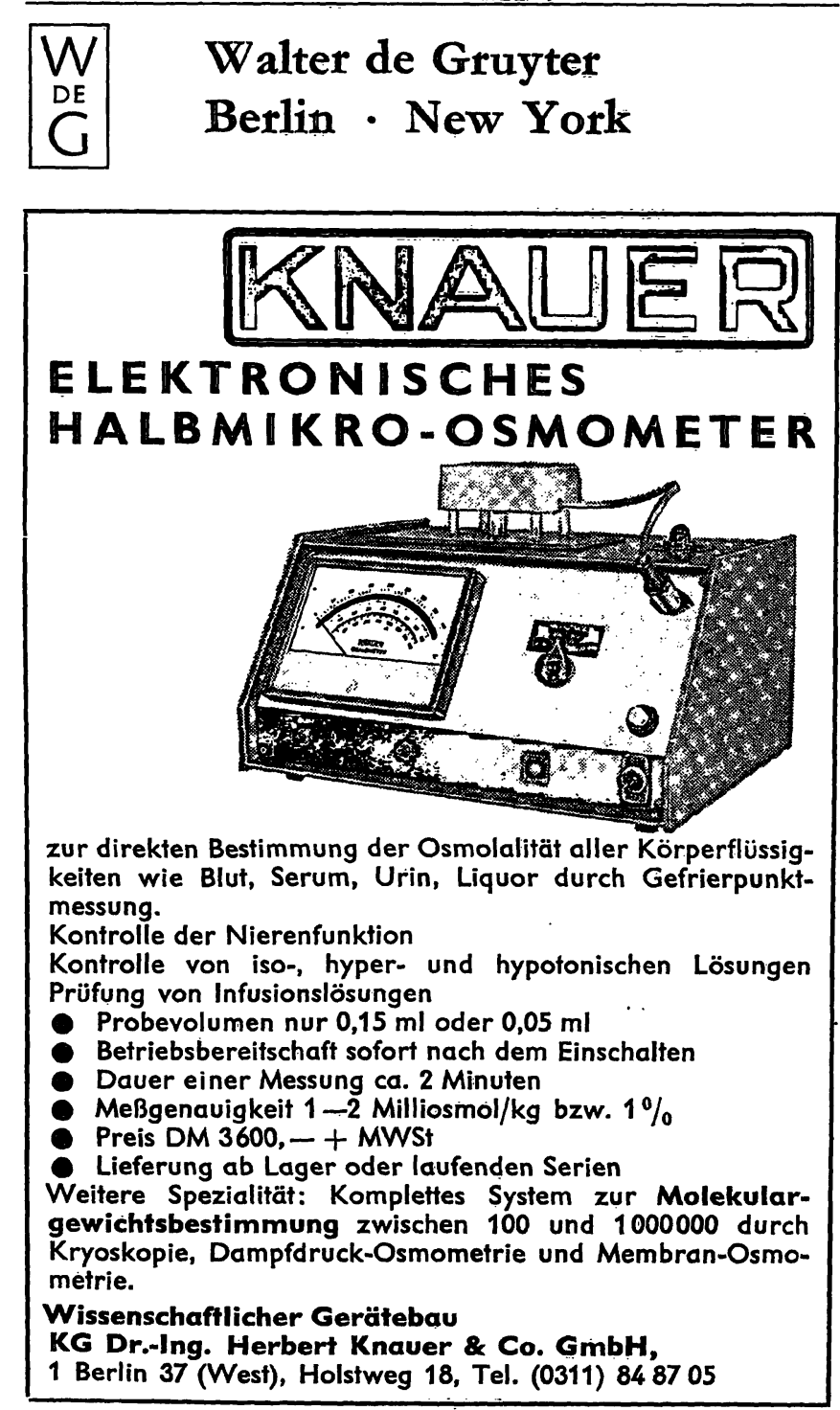

